\title{
Dissimilatory nitrate reduction by Aspergillus terreus isolated from the seasonal oxygen minimum zone in the Arabian Sea
}

Peter Stief ${ }^{1,2^{*}}$, Silvia Fuchs-Ocklenburg ${ }^{1,3}$, Anja Kamp ${ }^{1,4}$, Cathrine-Sumathi Manohar ${ }^{5}$, Jos Houbraken 6 , Teun Boekhout ${ }^{6,7}$, Dirk de Beer ${ }^{1}$ and Thorsten Stoeck ${ }^{3}$

\begin{abstract}
Background: A wealth of microbial eukaryotes is adapted to life in oxygen-deficient marine environments. Evidence is accumulating that some of these eukaryotes survive anoxia by employing dissimilatory nitrate reduction, a strategy that otherwise is widespread in prokaryotes. Here, we report on the anaerobic nitrate metabolism of the fungus Aspergillus terreus (isolate An-4) that was obtained from sediment in the seasonal oxygen minimum zone in the Arabian Sea, a globally important site of oceanic nitrogen loss and nitrous oxide emission.

Results: Axenic incubations of An-4 in the presence and absence of oxygen and nitrate revealed that this fungal isolate is capable of dissimilatory nitrate reduction to ammonium under anoxic conditions. $\mathrm{A}^{15} \mathrm{~N}$-labeling experiment proved that An-4 produced and excreted ammonium through nitrate reduction at a rate of up to $175 \mathrm{nmol}^{15} \mathrm{NH}_{4}^{+} \mathrm{g}^{-1}$ protein $\mathrm{h}^{-1}$. The products of dissimilatory nitrate reduction were ammonium (83\%), nitrous oxide (15.5\%), and nitrite (1.5\%), while dinitrogen production was not observed. The process led to substantial cellular ATP production and biomass growth and also occurred when ammonium was added to suppress nitrate assimilation, stressing the dissimilatory nature of nitrate reduction. Interestingly, An-4 used intracellular nitrate stores

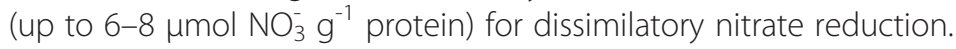

Conclusions: Our findings expand the short list of microbial eukaryotes that store nitrate intracellularly and carry out dissimilatory nitrate reduction when oxygen is absent. In the currently spreading oxygen-deficient zones in the ocean, an as yet unexplored diversity of fungi may recycle nitrate to ammonium and nitrite, the substrates of the major nitrogen loss process anaerobic ammonium oxidation, and the potent greenhouse gas nitrous oxide.
\end{abstract}

\section{Background}

In marine ecosystems, nitrate $\left(\mathrm{NO}_{3}^{-}\right)$serves as both a nitrogen source for assimilation and an electron acceptor for dissimilatory processes when oxygen $\left(\mathrm{O}_{2}\right)$ is deficient. The latter scenario is ubiquitously encountered in anoxic sediment layers, but also prevails in the water bodies of oxygen minimum zones (OMZs) of the world's oceans [1]. In denitrification, nitrate is sequentially reduced to dinitrogen $\left(\mathrm{NO}_{3}^{-} \rightarrow \mathrm{NO}_{2}^{-} \rightarrow \mathrm{NO} \rightarrow \mathrm{N}_{2} \mathrm{O} \rightarrow \mathrm{N}_{2}\right)$, in dissimilatory nitrate reduction to ammonium (DNRA), nitrate is

\footnotetext{
* Correspondence: peterstief@biology.sdu.dk

${ }^{1}$ Max Planck Institute for Marine Microbiology, Microsensor Group, Bremen, Germany

${ }^{2}$ Department of Biology, University of Southern Denmark, NordCEE,

Campusvej 55, 5230 Odense M, Denmark

Full list of author information is available at the end of the article
}

sequentially reduced to ammonium $\left(\mathrm{NO}_{3}^{-} \rightarrow \mathrm{NO}_{2}^{-} \rightarrow \mathrm{NH}_{4}^{+}\right)$, and in anaerobic ammonium oxidation (anammox), ammonium is oxidized by nitrite to form dinitrogen $\left(\mathrm{NH}_{4}^{+}+\mathrm{NO}_{2^{-}} \rightarrow \mathrm{N}_{2}\right)$. These different metabolic pathways of dissimilatory $\mathrm{NO}_{3}^{-}$or $\mathrm{NO}_{2}^{-}$reduction were originally thought to only occur in prokaryotes [2-4]. Meanwhile, denitrification and DNRA have been discovered in a limited set of eukaryotic microorganisms, including marine foraminifers $[5,6]$ and diatoms $[7,8]$. Incomplete denitrification to nitrous oxide $\left(\mathrm{N}_{2} \mathrm{O}\right)$ has also been proven for plantpathogenic and soil fungi, such as Fusarium oxysporum $[9,10]$, but so far not for marine isolates. Additionally, a large number of fungal species, mainly belonging to Ascomycota, are capable of "ammonia fermentation", a form of $\mathrm{NO}_{3}^{-}$reduction to ammonium $\left(\mathrm{NH}_{4}^{+}\right)$coupled to the fermentation of organic compounds [11]. 
Fungi are primarily aerobic heterotrophs, but some species, especially fermentative yeasts, can survive and grow under completely anoxic conditions. Nevertheless, both the abundance and the ecological role of fungi in $\mathrm{O}_{2}$-deficient marine environments are probably underestimated [12]. Recent sequencing approaches revealed a large diversity of marine microbial eukaryotes in environments where $\mathrm{O}_{2}$ occurs in low concentrations or is completely absent [13]. Additionally, it was found that fungal $18 \mathrm{~S}$ rDNA sequences dominate the eukaryotic microbial communities in anoxic marine habitats (reviewed by [14]). Fungi retrieved from coastal marine sediments are dominated by Ascomycota that may be of terrestrial origin [15]. Amongst others, they are represented by Aspergillus species, including $A$. terreus [16]. Fungal community structures differ between oxic, seasonally anoxic, and permanently anoxic sites, suggesting adaptation of fungal communities to prevailing $\mathrm{O}_{2}$ conditions [12].

The Arabian Sea harbors two different $\mathrm{O}_{2}$-deficient conditions, which includes a seasonal OMZ along the continental shelf and an open-ocean, perennial OMZ [17]. The distribution of anaerobic nitrogen cycling in the Arabian Sea is patchy and covers areas with predominant denitrification [18] or anammox activity [19]. The Arabian Sea is also a globally important site of $\mathrm{N}_{2} \mathrm{O}$ emission $[17,20,21]$. The oversaturation of the water column with this potent greenhouse gas is ascribed to denitrification activity [17].

Here, the ecophysiology of an A. terreus isolate (An-4) obtained from the seasonal OMZ in the Arabian Sea was studied. An-4 was enriched from coastal sediment sampled during a period of bottom-water anoxia using anoxic, $\mathrm{NO}_{3}^{-}$-amended conditions. It was therefore hypothesized that $\mathrm{An}-4$ is capable of dissimilatory $\mathrm{NO}_{3}^{-}$reduction. The role of $\mathrm{O}_{2}$ and $\mathrm{NO}_{3}^{-}$availability in triggering dissimilatory $\mathrm{NO}_{3}^{-}$reduction was studied in axenic incubations. In a dedicated ${ }^{15} \mathrm{~N}$-labeling experiment, all environmentally relevant products of dissimilatory $\mathrm{NO}_{3}^{-}$reduction were determined. Intracellular $\mathrm{NO}_{3}^{-}$storage, a common trait of $\mathrm{NO}_{3}^{-}$-respiring eukaryotes, was studied combining freezethaw cycles and ultrasonication for lysing $\mathrm{NO}_{3}^{-}$-storing cells. Production of cellular energy and biomass enabled by dissimilatory $\mathrm{NO}_{3}^{-}$reduction was assessed with ATP and protein measurements, respectively. Using these experimental strategies, we present the first evidence for dissimilatory $\mathrm{NO}_{3}^{-}$reduction by an ascomycete fungus that is known from a broad range of habitats, but here was isolated from a marine environment.

\section{Results}

Aerobic and anaerobic nitrate and ammonium turnover The fate of $\mathrm{NO}_{3}^{-}$added to the liquid media of axenic An-4. cultures (verified by microscopy and PCR screening, see
Methods) was followed during aerobic and anaerobic cultivation (Experiment 1), in a ${ }^{15} \mathrm{~N}$-labeling experiment involving an oxic-anoxic shift (Experiment 2), and in a cultivation experiment that addressed the intracellular storage of $\mathrm{NO}_{3}^{-}$ (Experiment 3 ). Nitrate was generally consumed, irrespective of $\mathrm{O}_{2}$ availability (Figures 1A + B (Exp. 1), 2A (Exp. 2), and $3 \mathrm{~A}+\mathrm{B}$ (Exp. 3)). Under oxic conditions, $\mathrm{NO}_{3}^{-}$concentrations in the liquid media exhibited sudden drops when high biomass production and/or $\mathrm{NH}_{4}^{+}$depletion was noted in the culture flasks (Figures $1 \mathrm{~A}$ and $3 \mathrm{~A}$ ). Under anoxic conditions, however, $\mathrm{NO}_{3}^{-}$concentrations in the liquid media decreased steadily over the whole incubation period during which neither sudden increases in biomass production, nor $\mathrm{NH}_{4}^{+}$depletion were noted (Figures 1B, 2A, and $3 \mathrm{~B})$.

The fate of $\mathrm{NH}_{4}^{+}$was investigated in Experiments 1 and 2 and additionally in an experiment that addressed the production of biomass and cellular energy during aerobic and anaerobic cultivation (Experiment 4). Ammonium was either net consumed or net produced, which depended on the availability of both $\mathrm{O}_{2}$ and $\mathrm{NO}_{3}^{-}$ (Figures $1 \mathrm{~A}+\mathrm{B}, 2 \mathrm{~B}+\mathrm{C}$, and 4A (Exp. 4)). In the absence of $\mathrm{NO}_{3^{-}}, \mathrm{NH}_{4^{+}}$was invariably consumed, irrespective of $\mathrm{O}_{2}$

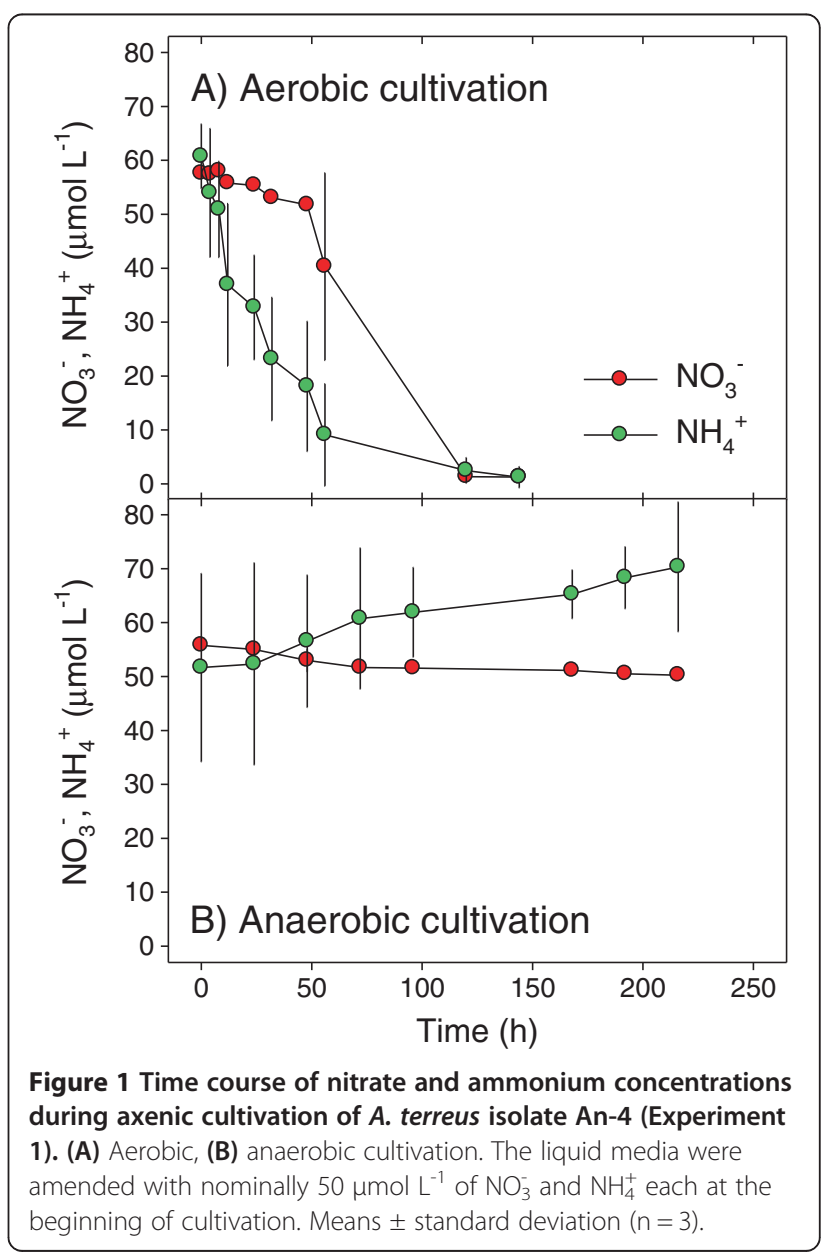




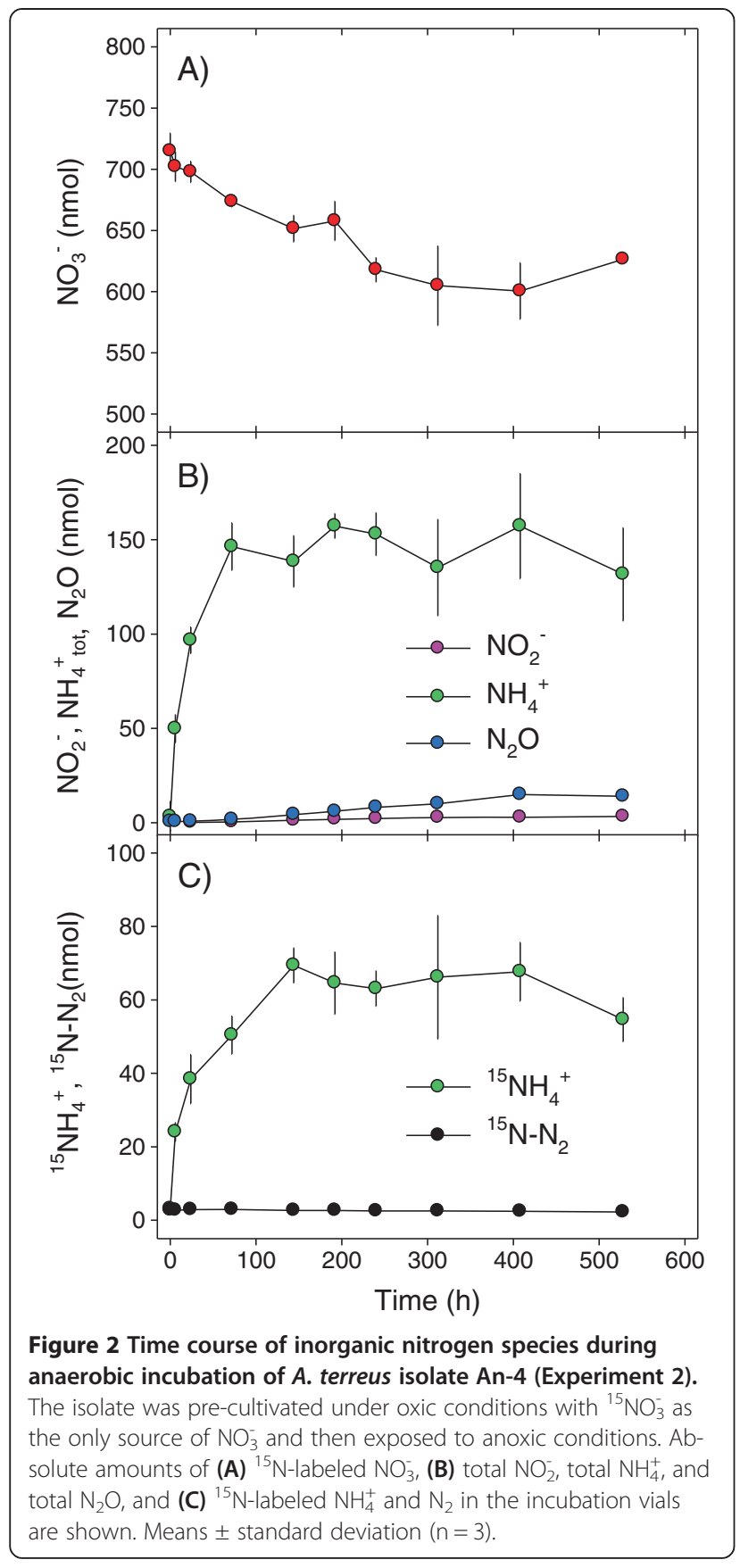

availability (Figure 4A). In the presence of $\mathrm{NO}_{3}^{-}, \mathrm{NH}_{4}^{+}$ was either consumed or produced under oxic and anoxic conditions, respectively (Figures $1 \mathrm{~A}+\mathrm{B}, 2 \mathrm{~B}+\mathrm{C}$, and $4 \mathrm{~A}$ ). Taken together, these results suggest a role of $\mathrm{NO}_{3}^{-}$in nitrogen assimilation under oxic conditions when $\mathrm{NH}_{4}^{+}$is depleted, and a role of $\mathrm{NO}_{3}^{-}$in dissimilation under anoxic conditions when $\mathrm{NH}_{4}^{+}$is available. Additionally, the net production of $\mathrm{NH}_{4}^{+}$under anoxic conditions suggests dissimilatory $\mathrm{NO}_{3}^{-}$reduction to $\mathrm{NH}_{4}^{+}$by An-4.

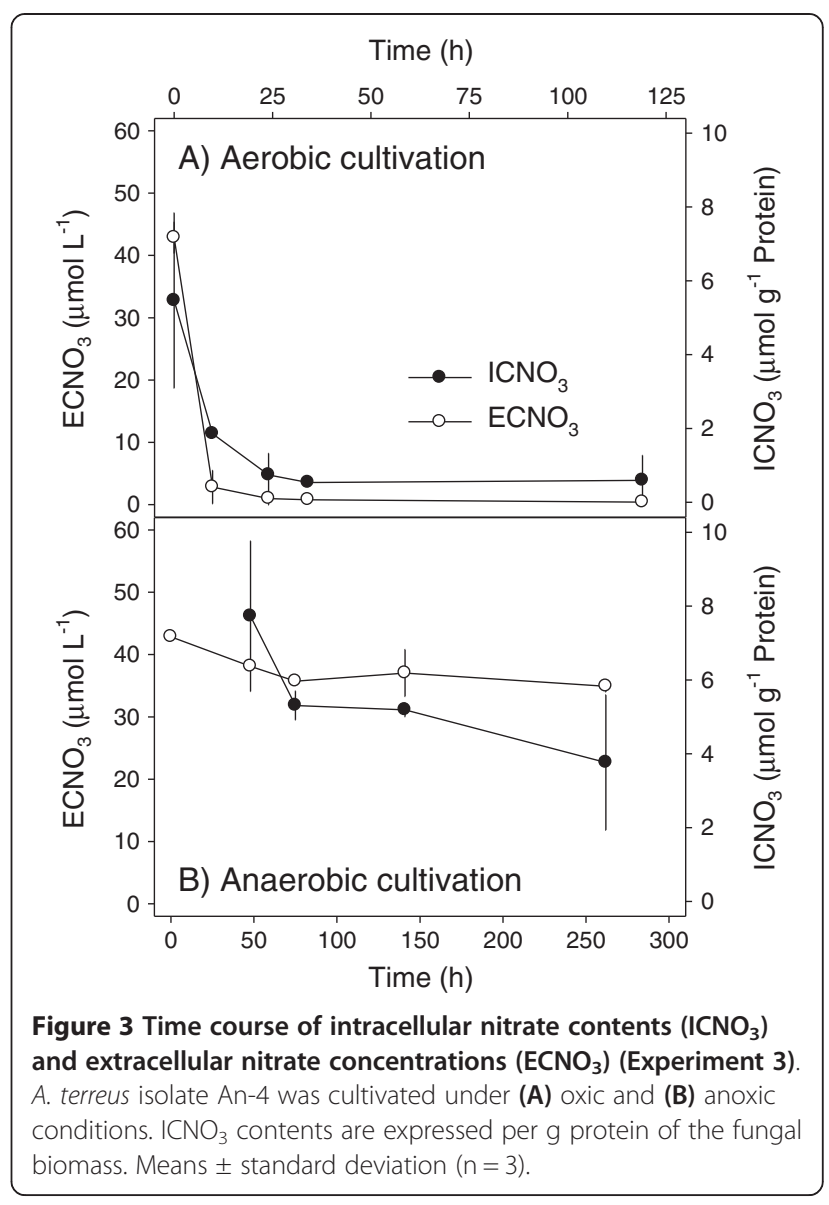

Products of anaerobic nitrate turnover

The precursors, intermediates, and end products of dissimilatory $\mathrm{NO}_{3}^{-}$reduction (i.e., $\mathrm{NO}_{3}^{-}, \mathrm{NO}_{2}^{-}, \mathrm{NH}_{4}^{+}, \mathrm{N}_{2} \mathrm{O}$, and $\mathrm{N}_{2}$ ) by An- 4 were investigated in a ${ }^{15} \mathrm{~N}$-labeling experiment (Exp. 2). Axenic mycelia were incubated with ${ }^{15} \mathrm{NO}_{3}^{-}$and then subjected to a sudden oxic-anoxic shift. The anaerobic consumption of $\mathrm{NO}_{3}^{-}$by An-4 was accompanied by the production and cellular release of $\mathrm{NH}_{4}^{+}, \mathrm{NO}_{2}^{-}$, and $\mathrm{N}_{2} \mathrm{O}$, but not $\mathrm{N}_{2}$ (Figure 2A-C). Ammonium was quantitatively by far the most important product, whereas $\mathrm{N}_{2} \mathrm{O}$ and $\mathrm{NO}_{2}^{-}$were less important (Figure 2B $+\mathrm{C}$, Table 1, Additional file 1: Figure S1). Biomass-specific ${ }^{15} \mathrm{NH}_{4}^{+}$production rates equaled ${ }^{15} \mathrm{NO}_{3}^{-}$ consumption rates during the first 3 days of incubation (Table 1). During the remaining incubation time, $\mathrm{N}$ consumption and production rates were generally lower than during the first 3 days (Table 1). After no further decrease of the $\mathrm{NO}_{3}^{-}$concentration was observed (i.e., after $408 \mathrm{~h}$ ), $\mathrm{NH}_{4}^{+}, \mathrm{N}_{2} \mathrm{O}$, and $\mathrm{NO}_{2}^{-}$formed 83.0, 15.5, and $1.5 \%$, respectively, of all $\mathrm{N}$ produced and released into the liquid media. These results substantiate the capability of An-4 to dissimilatorily reduce $\mathrm{NO}_{3}^{-}$to $\mathrm{NH}_{4}^{+}$(as main product), $\mathrm{NO}_{2}^{-}$and $\mathrm{N}_{2} \mathrm{O}$ (as side products) under anoxic conditions. 


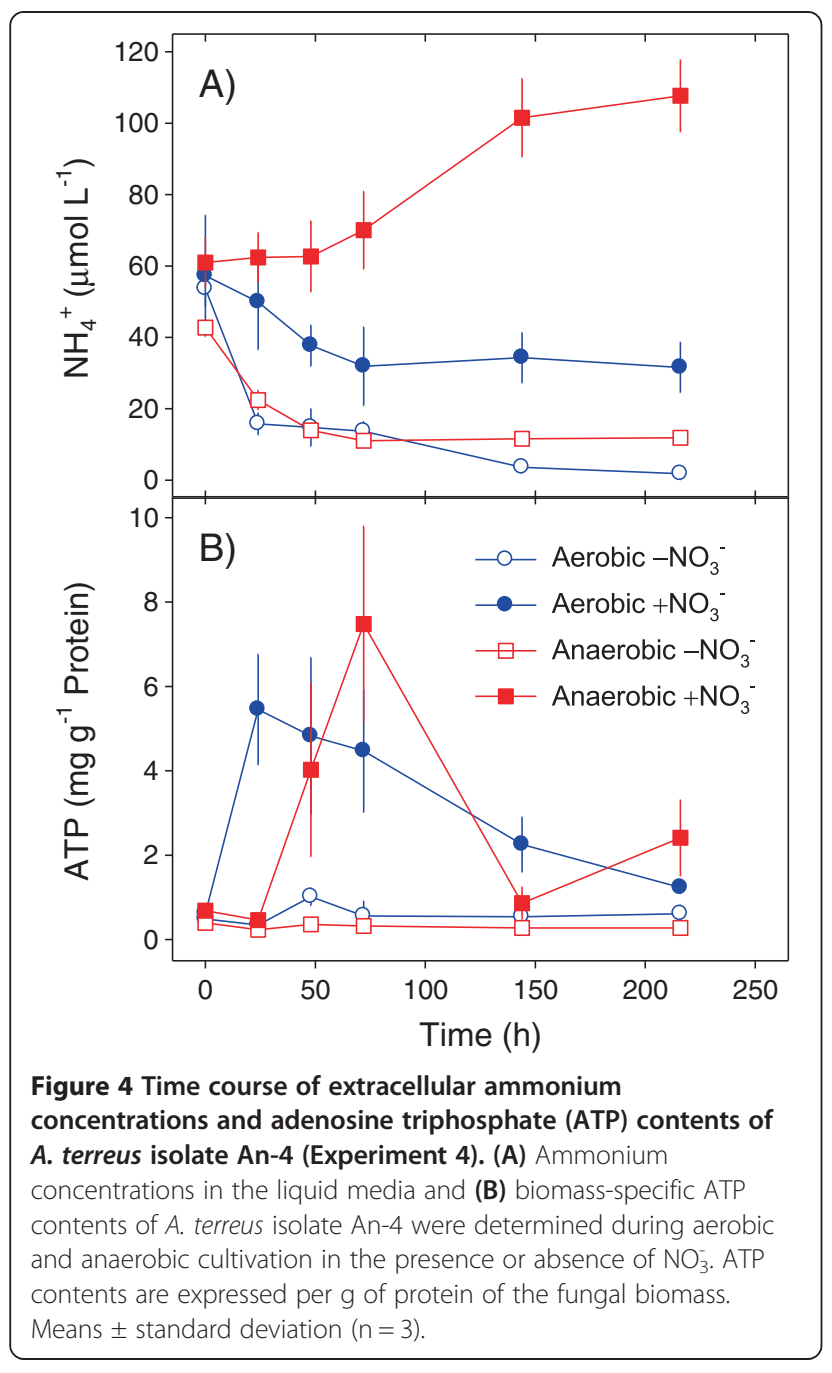

\section{Intracellular nitrate storage}

The capability of An-4 to store nitrate intracellularly, a common trait of large-celled microorganisms that respire nitrate, was investigated during both aerobic and anaerobic cultivation (Exp. 3). Intracellular $\mathrm{NO}_{3}^{-}$concentrations $\left(\mathrm{ICNO}_{3}\right)$ were high when extracellular $\mathrm{NO}_{3}^{-}$concentrations $\left(\mathrm{ECNO}_{3}\right)$ were high and vice versa, irrespective of $\mathrm{O}_{2}$ availability (Figure $3 \mathrm{~A}+\mathrm{B}$ ). Under oxic conditions, however, $\mathrm{ICNO}_{3}$ and $\mathrm{ECNO}_{3}$ concentrations dropped sharply within the first day of incubation (Figure 3A), whereas under anoxic conditions, steady decreases in $\mathrm{ICNO}_{3}$ and $\mathrm{ECNO}_{3}$ concentrations were noted during 11 days of incubation (Figure 3B).

In the ${ }^{15} \mathrm{~N}$-labeling experiment (Exp. 2), the total amount of $\mathrm{N}$ produced in each incubation vial (185.4 \pm $29.3 \mathrm{nmol}$ ) exceeded the total amount of $\mathrm{NO}_{3}^{-}$consumed $(114.4 \pm 27.3 \mathrm{nmol})$, implying that also $71.0 \mathrm{nmol} \mathrm{ICNO}_{3}$ was consumed during the anoxic incubation. The initial amount of $\mathrm{ICNO}_{3}$ transferred into the incubation vials together with the An-4 mycelia of $77.5 \pm 28.9 \mathrm{nmol}$
Table 1 Turnover rates of inorganic nitrogen species by A. terreus isolate An-4 during anaerobic incubation with ${ }^{15} \mathrm{NO}_{3}^{-}$enrichment (Experiment 2)

\begin{tabular}{lrr}
\hline Nitrogen species & \multicolumn{1}{c}{ Day 0-3 } & Day 3-17 \\
\hline $\mathrm{NO}_{3 \text { total }}^{-}$ & $-166.5(33.9)$ & $-76.4(13.3)$ \\
$\mathrm{NO}_{2 \text { total }}^{-}$ & $+3.4(0.4)$ & $+1.5(0.3)$ \\
$\mathrm{NH}_{4}^{+}$ & $+565.4(74.8)$ & $+6.1(12.4)$ \\
$\mathrm{N}_{2} \mathrm{O}_{\text {total }}$ & $+5.0(0.7)$ & $+12.5(0.9)$ \\
${ }^{15} \mathrm{NH}_{4}^{+}$ & $+175.4(33.7)$ & $+11.1(6.5)$ \\
${ }^{15} \mathrm{~N}_{-} \mathrm{N}_{2}$ & $+0.7(0.8)$ & $-0.4(0.2)$ \\
\hline
\end{tabular}

Rates were calculated for linear increases or decreases in the amount of the different nitrogen species during the early and late phase of anaerobic incubation. Mean rates (standard error) are given as $\mathrm{nmol} \mathrm{N} \mathrm{g}{ }^{-1}$ protein $\mathrm{h}^{-1}$. Positive and negative values indicate production and consumption, respectively.

equaled the calculated amount of $\mathrm{ICNO}_{3}$ needed to close the $\mathrm{N}$ budget.

\section{Production of biomass and cellular energy}

The production of biomass and cellular energy by An- 4 was studied during aerobic and anaerobic cultivation in the presence or absence of $\mathrm{NO}_{3}^{-}$(Experiment 4); biomass production was also recorded in Experiment 1. For this purpose, the time courses of protein and ATP contents of An-4 mycelia and of $\mathrm{NO}_{3}^{-}$and $\mathrm{NH}_{4}^{+}$concentrations in the liquid media were followed. Biomass production by An-4 was significantly higher when $\mathrm{O}_{2}$ and/or $\mathrm{NO}_{3}^{-}$were available in the liquid media (Table 2). The biomassspecific ATP contents of An- 4 reached higher values when $\mathrm{NO}_{3}^{-}$was available in the liquid media and were invariably low in its absence (Figure 4B). Under oxic conditions, ATP contents increased to maximum values within 1 day of incubation and steadily decreased during the following 8 days (Figure 4B). Under anoxic conditions, ATP contents reached maximum values only after 3 days and thereafter fluctuated around intermediate values (Figure 4B). These results substantiate the capability of An-4 to grow anaerobically and produce cellular energy by dissimilatory $\mathrm{NO}_{3}^{-}$reduction to $\mathrm{NH}_{4}^{+}$.

\section{Discussion}

\section{Physiology of isolate An-4}

All observations made during incubations of Aspergillus terreus (isolate An-4) in the presence and absence of $\mathrm{O}_{2}$ and $\mathrm{NO}_{3}^{-}$indicate that this fungus is capable of dissimilatory $\mathrm{NO}_{3}^{-}$reduction to $\mathrm{NH}_{4}^{+}$[11]. An-4 produced $\mathrm{NH}_{4}^{+}$ only under anoxic conditions and through $\mathrm{NO}_{3}^{-}$reduction as proven in the ${ }^{15} \mathrm{~N}$-labeling experiment. The process led to significant cellular ATP production and biomass growth and also occurred when $\mathrm{NH}_{4}^{+}$was added to suppress $\mathrm{NO}_{3}^{-}$assimilation, stressing the dissimilatory nature of the observed anaerobic $\mathrm{NO}_{3}^{-}$reduction activity. For a large number of other fungal species, this type of 
Table 2 Correlation between oxygen and nitrate availability and biomass production by $A$. terreus isolate An-4 (Experiments 1 and 4)

\begin{tabular}{llcc}
\hline Experiment & Treatment & Nitrate in media $(\boldsymbol{\mu M})$ & Final biomass in flask $(\mathbf{g})$ \\
\hline Experiment 1 & Aerobic + Nitrate & $43.2(1.7)$ & $11.4(1.5)$ \\
Experiment 4 & Anaerobic + Nitrate & $52.3(0.5)$ & $1.5(0.1)$ \\
& Aerobic - Nitrate & $3.4(0.1)$ & $2.2(0.4)$ \\
& Aerobic + Nitrate & $30.6(2.7)$ & $11.2(1.0)$ \\
& Anaerobic - Nitrate & $6.6(0.1)$ & $0.7(0.1)$ \\
& Anaerobic + Nitrate & $95.4(8.7)$ & $2.3(1.8)$ \\
\hline
\end{tabular}

Nitrate concentrations are given as the mean (standard deviation) of 6-10 samples taken during the cultivation period. Final biomass is given as the mean (standard deviation) wet weight of three fungal cultures harvested at the end of the cultivation period. The final biomass does not include the (minor) weight of six samples that were taken for protein and ATP analysis in Experiment 4.

anaerobic $\mathrm{NO}_{3}^{-}$metabolism has been termed "ammonia fermentation" in case that the reduction of $\mathrm{NO}_{3}^{-}$to $\mathrm{NH}_{4}^{+}$ was coupled to the oxidation of organic carbon compounds to acetate and substrate-level phosphorylation $[10,11]$. Ammonia fermentation has been found in a wide spectrum of filamentous ascomycetous fungi $[11,22]$, but so far not in fungi isolated from marine environments. Since the fermentation of organic substrates is not proven for An-4, the anaerobic $\mathrm{NO}_{3}^{-}$metabolism of this isolate might as well be of respiratory nature and then corresponds to DNRA. This pathway has so far been excluded to occur in fungi because a pentaheme cytochrome $c \mathrm{NO}_{2}^{-}$reductase typical of DNRA [23] has not been found in fungi with an anaerobic $\mathrm{NO}_{3}^{-}$metabolism [24].

Aside from the general accord with fungal ammonia fermentation or DNRA, the anaerobic $\mathrm{NO}_{3}^{-}$metabolism of An-4 showed several interesting features. Most notably, dissimilatory $\mathrm{NO}_{3}^{-}$reduction was accompanied by significant $\mathrm{N}_{2} \mathrm{O}$ production (ca. $15 \%$ of $\mathrm{NO}_{3}^{-}$reduced) and to a lesser extent by $\mathrm{NO}_{2}^{-}$production (ca. $1.5 \%$ of $\mathrm{NO}_{3}^{-}$reduced). While it was not surprising that traces of $\mathrm{NO}_{2}^{-}$, an intermediate of dissimilatory $\mathrm{NO}_{3}^{-}$reduction to $\mathrm{NH}_{4}^{+}$, were released into the liquid media $[8,11]$, the production and cellular release of $\mathrm{N}_{2} \mathrm{O}$ was unexpected [10]. Nitrous oxide is the end product of incomplete denitrification in many plant-pathogenic and soil fungi $[9,25,26]$, whereas the marine isolate An-4 obviously produces $\mathrm{N}_{2} \mathrm{O}$ via dissimilatory $\mathrm{NO}_{3}^{-}$reduction to $\mathrm{NH}_{4}^{+}$. Nitrous oxide is not generally known as an intermediate of dissimilatory $\mathrm{NO}_{3}^{-}$reduction to $\mathrm{NH}_{4}^{+}$, but may well be a by-product of this reduction pathway as shown for bacteria [27-29].

An-4 is clearly able to store $\mathrm{NO}_{3}^{-}$intracellularly and use it for dissimilatory $\mathrm{NO}_{3}^{-}$reduction to $\mathrm{NH}_{4}^{+}$. Intracellular $\mathrm{NO}_{3}^{-}$storage is known for a number of prokaryotic and eukaryotic microorganisms capable of dissimilatory $\mathrm{NO}_{3}^{-}$ reduction, but so far has not been reported for fungi, even when capable of denitrification or ammonia fermentation $[10,24]$. Large sulfide-oxidizing bacteria [30,31], foraminifers and gromiids [5,6,32,33], and diatoms [7,8,34,35] store $\mathrm{NO}_{3}^{-}$in their cells in millimolar concentrations. In our experiments with An-4, the maximum biomassspecific intracellular $\mathrm{NO}_{3}^{-}$contents were $6-8 \mu \mathrm{mol} \mathrm{g}{ }^{-1}$ protein. Assuming a cellular protein content of $50 \%$ of the dry weight and a cellular water content of $90 \%$ of the wet weight, maximum intracellular nitrate concentrations reached ca. $400 \mu \mathrm{mol} \mathrm{L}{ }^{-1}$. This intracellular $\mathrm{NO}_{3}^{-}$pool proved to be quantitatively important for dissimilatory $\mathrm{NO}_{3}^{-}$reduction by An-4, since it contributed up to $38 \%$ to the total $\mathrm{NO}_{3}^{-}$consumption in the ${ }^{15} \mathrm{~N}$-labeling experiment. The initially high rates of $\mathrm{NH}_{4}^{+}$production may suggest that An-4 is first using up the readily available intracellular $\mathrm{NO}_{3}^{-}$stores before it switches to using extracellular $\mathrm{NO}_{3}^{-}$as well, but this scenario needs to be proven in a dedicated ${ }^{15} \mathrm{~N}$-labeling experiment. The general physiology of intracellular $\mathrm{NO}_{3}^{-}$storage by An-4 is currently unknown. For instance, it is not clear at which growth stage and under which ambient conditions An-4 is taking up $\mathrm{NO}_{3}^{-}$from the environment because the phase of increasing intracellular $\mathrm{NO}_{3}^{-}$contents was not captured by our oxic and anoxic incubations. From the observed correlation between $\mathrm{ICNO}_{3}$ and $\mathrm{ECNO}_{3}$ it can be concluded that an unknown enrichment factor cannot be exceeded, meaning that $\mathrm{ICNO}_{3}$ concentrations will increase with $\mathrm{ECNO}_{3}$ concentrations, probably up to an as yet unknown maximum $\mathrm{ICNO}_{3}$ concentration. Benthic microorganisms that store $\mathrm{NO}_{3}^{-}$often show vertical migration behavior in the sediment that may enable them to take up $\mathrm{NO}_{3}^{-}$closer to the sediment surface and in the presence of $\mathrm{O}_{2}$ [30,36,37]. It is conceivable that the hyphae of An-4 grow in direction of $\mathrm{NO}_{3}^{-}$-containing layers closer to the sediment surface to facilitate $\mathrm{NO}_{3}^{-}$uptake. Finally, it remains to be investigated whether An-4 accumulates $\mathrm{NO}_{3}^{-}$in acidic vacuoles as recently shown for large sulfur bacteria [38] or in the cytosol of the hyphae.

\section{Ecological implications of anaerobic nitrate turnover by isolate An-4}

Aspergillus terreus is a common and globally occurring soil fungus that is also known from substrates as diverse 
as air, salterns, capybara droppings, lung of pocket mice, corn, cotton plants, milled rice, muesli, and wall paint [39]. The species has been reported from marine and associated habitats, such as mangroves and soft corals, and isolates from these habitats have been widely investigated for the production of bioactive compounds [40-42]. A. terreus has also been isolated from the hypersaline water of the Dead Sea [43,44]. The species is an important human pathogen causing bronchopulmonary aspergillosis and disseminated infections [45]. Dissimilatory $\mathrm{NO}_{3}^{-}$reduction by human-associated microorganisms has been demonstrated $[46,47]$, but it is not known whether fungi are involved. A. terreus is also of considerable biotechnological interest because it produces a wide diversity of secondary metabolites that find pharmaceutical applications, biotechnologically relevant compounds such as itaconic acid and itatartaric acid, as well as mycotoxins that are important for food safety ([39] and references therein).

The wide habitat spectrum of $A$. terreus might be significantly expanded by the ability for dissimilatory $\mathrm{NO}_{3}^{-}$ reduction in the absence of $\mathrm{O}_{2}$. This fungus has the potential to survive hypoxic or anoxic conditions that prevail in aquatic sediments mostly just a few millimeters below the surface [48] or even directly at the surface when $\mathrm{O}_{2}$ concentrations are low in the water column $[12,49]$. In contrast, $\mathrm{NO}_{3}^{-}$originating from the water column and/or the nitrification layer at the sediment surface diffuses deeper into the sediment than $\mathrm{O}_{2}$ does [50]. In shallow sediments, $\mathrm{NO}_{3}^{-}$-rich water is introduced into even deeper layers by mixing forces such as bioturbation, bioirrigation, and ripple movement [51,52]. The sediment habitat in which $A$. terreus can thrive is further expanded by its $\mathrm{NO}_{3}^{-}$storage capability. The maximum intracellular $\mathrm{NO}_{3}^{-}$content of $8 \mu \mathrm{mol} \mathrm{g}^{-1}$ protein theoretically sustains dissimilatory $\mathrm{NO}_{3}^{-}$reduction without extracellular $\mathrm{NO}_{3}^{-}$supply for 2-4.5 days (calculated from rates measured in the ${ }^{15} \mathrm{~N}$-labeling experiment). Survival and growth beyond this time frame will depend on the ability of $A$. terreus to repeatedly access $\mathrm{NO}_{3}^{-}$in its natural sediment habitat, which is currently unknown.

The dissimilatory $\mathrm{NO}_{3}^{-}$reduction activity of An-4 leads to the production and release of $\mathrm{NH}_{4}^{+}, \mathrm{N}_{2} \mathrm{O}$, and $\mathrm{NO}_{2}^{-}$. Thus, unlike the denitrification and anammox activities of other microorganisms, the anaerobic $\mathrm{NO}_{3}^{-}$metabolism of An-4 cannot directly lead to fixed nitrogen removal. Since the major product of $\mathrm{NO}_{3}^{-}$reduction is $\mathrm{NH}_{4}^{+}, \mathrm{An}-4$ merely converts one form of fixed nitrogen into another one. It is noteworthy, however, that the production of $\mathrm{NH}_{4}^{+}$and $\mathrm{NO}_{2}^{-}$by An-4 might indirectly contribute to fixed nitrogen removal by fueling anammox, the dominant nitrogen loss process in many OMZs [53]. Remarkably, An-4 produces and releases ca. $15 \%$ of the total $\mathrm{NO}_{3}^{-}$reduced as $\mathrm{N}_{2} \mathrm{O}$, a potent greenhouse gas $[54,55]$.
Interestingly, the OMZs of the Arabian Sea have repeatedly been reported to be major sites of $\mathrm{N}_{2} \mathrm{O}$ production, especially in continental shelf areas and coastal upwelling zones $[17,20,21,56]$.

\section{Conclusion}

Before meaningful conclusions on the potential impact of fungi on the marine nitrogen cycle can be drawn, it has to be established how abundant and widespread fungi with an anaerobic $\mathrm{NO}_{3}^{-}$metabolism are in marine environments. Previous studies reported a high diversity of fungi in $\mathrm{O}_{2}$-deficient marine environments $[12,16]$, a large proportion of which may have similar physiologies as An-4. Therefore, further concerted efforts should aim at revealing the so far largely ignored influence of fungi on the marine nitrogen cycle and their role in the production of greenhouse gases.

\section{Methods}

\section{Geographic origin and identity of isolate An-4}

The sampling site was located in the coastal, seasonal OMZ off Goa (India), northwest of the river mouths of the Zuari and the Mandovi $\left(15^{\circ} 31^{\prime} 80^{\prime \prime} \mathrm{N}, 73^{\circ} 42^{\prime} 60^{\prime \prime} \mathrm{E}\right)$. Sampling was carried out at $14 \mathrm{~m}$ water depth in October 2005 and anoxic conditions were recorded in the bottom waters during sampling. Four ascomycete fungi were successfully isolated by the particle-plating technique after enrichment in anoxic, nitrate-amended seawater. One of the ascomycete isolates (An-4) was axenized with antibiotics and is tested here for its capability to reduce nitrate in the absence of oxygen.

Isolate An-4 was identified as Aspergillus terreus (Order Eurotiales, Class Eurotiomycetes) using morphological and DNA sequence data. Macro- and microscopic characters were studied according to [39]. Partial calmodulin (Cmd) and $\beta$-tubulin (BenA) gene sequences retrieved from the isolate with previously described methods $[57,58]$ were used to derive the phylogenetic position of An-4 (Additional file 1: Figure S2). The obtained sequences were deposited in the NCBI GenBank sequence database under accession numbers [KJ146014] (Cmd) and [KJ146013] (BenA). The isolate was deposited in the culture collection of the CBS-KNAW Fungal Biodiversity Centre as [CBS 136781] and at the Microbial Type Culture Collection and Gene Bank (MTCC, Chandigarh, India) as [MTCC 11865].

\section{Cultivation for anaerobic nitrate turnover experiments}

An-4 was pre-grown on agar plates prepared from YMG broth (i.e., Yeast extract $\left[8 \mathrm{~g} \mathrm{~L}^{-1}\right]+$ Malt extract $\left[10 \mathrm{~g} \mathrm{~L}^{-}\right.$ $\left.{ }^{1}\right]+$ Glucose $\left.\left[10 \mathrm{~g} \mathrm{~L}^{-1}\right]\right)$ supplemented with penicillin and streptomycin. Every few plate transfers, the antibiotics were omitted to avoid emergence and carry-over of resistant bacteria. Spores of the axenic isolate grown on 
agar plates were used to inoculate 500-mL Erlenmeyer flasks that contained $250 \mathrm{~mL}$ of YMG broth. For aerobic cultivation, the flasks were closed with aseptic cotton plugs. The flasks were placed on a rotary shaker (120 rpm) and incubated at $26^{\circ} \mathrm{C}$. Under these conditions, the mycelia of An-4 formed spherical aggregates of $2-5 \mathrm{~mm}$ in diameter. The transfers from plate to flask were repeated every $3-4$ weeks.

\section{Anaerobic nitrate turnover}

The capability of An-4 to reduce nitrate anaerobically was investigated in two experiments: (1) An-4 was cultivated in Erlenmeyer flasks under oxic vs. anoxic conditions in the presence of both $\mathrm{NO}_{3}^{-}$and $\mathrm{NH}_{4}^{+}$, and (2) An4 was pre-cultivated in Erlenmeyer flasks under oxic conditions in the presence of ${ }^{15} \mathrm{NO}_{3}^{-}$and then exposed to anoxic conditions in gas-tight incubation vials.

In Experiment 1, the fate of $\mathrm{NO}_{3}^{-}$and $\mathrm{NH}_{4}^{+}$added to the liquid media was followed during aerobic and anaerobic cultivation of An-4. Six replicate liquid cultures were prepared as described above, but with the YMG broth adjusted to nominal concentrations of $50 \mu \mathrm{mol} \mathrm{L}^{-1}$ $\mathrm{NO}_{3}^{-}$and $50 \mu \mathrm{mol} \mathrm{L}-1 \mathrm{NH}_{4}^{+}$using aseptic $\mathrm{NaNO}_{3}$ and $\mathrm{NH}_{4} \mathrm{Cl}$ stock solutions, respectively. Three cultures were incubated aerobically, whereas the other three cultures were incubated anaerobically by flushing the Erlenmeyer flasks with dinitrogen for $30 \mathrm{~min}$ and then closing them with butyl rubber stoppers. Subsamples of the liquid media $(1.5 \mathrm{~mL})$ were taken after defined time intervals using aseptic techniques. Anaerobic cultures were sampled in an argon-flushed glove box to avoid intrusion of $\mathrm{O}_{2}$ into the Erlenmeyer flasks. Samples were immediately frozen at $-20^{\circ} \mathrm{C}$ for later analysis of $\mathrm{NO}_{3}^{-}$and $\mathrm{NH}_{4}^{+}$ concentrations.

In Experiment 2, the precursors, intermediates, and end products of dissimilatory nitrate reduction by An-4 were investigated in a ${ }^{15} \mathrm{~N}$-labeling experiment, involving an oxic-anoxic shift imposed on axenic mycelia. For the aerobic pre-cultivation, a liquid culture was prepared as described above, but with the YMG broth adjusted to $120 \mu \mathrm{mol} \mathrm{L}-1{ }^{15} \mathrm{NO}_{3}^{-}$(98 atom\% ${ }^{15} \mathrm{~N}$; Sigma-Aldrich). For anaerobic incubation, fungal aggregates were transferred to gas-tight glass vials $(5.9-\mathrm{mL}$ exetainers; Labco, Wycombe, UK) filled with anoxic $\mathrm{NaCl}$ solution (2\%) amended with nitrate as electron acceptor and glucose as electron donor. Using aseptic techniques, equallysized subsamples of fungal aggregates were transferred from the aerobic pre-cultures into 30 replicate exetainers. The wet weight of the aggregates was determined. Then the exetainers were filled with anoxic $\mathrm{NaCl}$ solution adjusted to $120 \mu \mathrm{mol} \mathrm{L} \mathrm{L}^{-1}{ }^{15} \mathrm{NO}_{3}^{-}$and $25 \mu \mathrm{mol} \mathrm{L}{ }^{-1}$ glucose. Care was taken not to entrap any gas bubbles when the exetainers were closed with the septum cap. The exetainers were fixed in a rack that was continuously rotated to keep the aggregates in suspension and were incubated at $26^{\circ} \mathrm{C}$ in the dark for 24 days.

The anaerobic incubation was terminated in batches of three exetainers after defined time intervals. Subsamples of the liquid media were withdrawn through the septum (and simultaneously replaced with helium) for analyzing the concentrations of extracellular $\mathrm{NO}_{3}^{-}, \mathrm{NO}_{2}^{-}$, $\mathrm{NH}_{\text {thotal }}^{+},{ }^{15} \mathrm{NH}_{4}^{+}$, and $\mathrm{N}_{2} \mathrm{O}$, while the concentrations of ${ }^{15} \mathrm{~N}-\mathrm{N}_{2} \mathrm{O}$ and ${ }^{15} \mathrm{~N}-\mathrm{N}_{2}$ were determined directly in the incubation exetainers. For $\mathrm{NO}_{3}^{-}, \mathrm{NO}_{2}^{-}$, and $\mathrm{NH}_{\text {tital }}^{+}$analysis, $1.5 \mathrm{~mL}$ of the liquid media was immediately frozen at $-20^{\circ} \mathrm{C}$. For $\mathrm{N}_{2} \mathrm{O}$ analysis, $1 \mathrm{~mL}$ of the liquid media was immediately transferred into an $\mathrm{N}_{2}$-purged 3-mL exetainer and fixed with $100 \mu \mathrm{L} \mathrm{ZnCl}_{2}$ (50\%). For ${ }^{15} \mathrm{NH}_{4}^{+}$analysis, $0.5 \mathrm{~mL}$ of the liquid media was transferred into a $3-\mathrm{mL}$ exetainer and frozen at $-20^{\circ} \mathrm{C}$. The liquid media remaining in the incubation exetainers were fixed with $100 \mu \mathrm{L} \mathrm{ZnCl} 2$ (50\%) for later ${ }^{15} \mathrm{~N}-\mathrm{N}_{2} \mathrm{O}$ and ${ }^{15} \mathrm{~N}-\mathrm{N}_{2}$ analysis. For technical reasons, ${ }^{15} \mathrm{~N}-\mathrm{N}_{2} \mathrm{O}$ could not be quantified for this specific experiment, but only for a slightly modified twin experiment the results of which are presented in the Supporting Information.

Additional exetainers with fungal aggregates were prepared and treated in the same way as the other exetainers for verifying that An-4 remained axenic throughout the anaerobic incubation. At the end of the experiment, these exetainers were opened using aseptic techniques and subsamples of both fungal aggregates (at least two) and liquid medium $(100 \mu \mathrm{L})$ were plated on YMG agar. After incubation at $26^{\circ} \mathrm{C}$ for 15 days, the fungal colonies were carefully checked by microscopy for the presence of bacteria and xenic fungi. All microscopic checks were negative. Additionally, DNA was extracted from fungal aggregates and liquid medium with the UltraClean ${ }^{\text {th }}$ Soil DNA Isolation Kit (Mo Bio, Carlsbad, CA) and used as template for PCR targeting the 16S rRNA gene with the universal bacterial primers GM3F/GM4R [59]. All molecular checks were negative, since agarose gel electrophoresis did not reveal any specific amplification product except for in the positive control, a laboratory strain of Agrobacterium sp.

\section{Intracellular nitrate storage}

The capability of An-4 to store nitrate intracellularly was investigated during both aerobic and anaerobic cultivation (Experiment 3). Liquid cultures were prepared as described above, but with the YMG broth adjusted to $50 \mu \mathrm{mol} \mathrm{L}{ }^{-1} \mathrm{NO}_{3}^{-}$. After defined time intervals, YMG broth and fungal aggregates were subsampled for analysis of $\mathrm{NO}_{3}^{-}$freely dissolved in the broth (i.e., extracellular nitrate $=\mathrm{ECNO}_{3}$ ) and $\mathrm{NO}_{3}^{-}$contained within the fungal hyphae (i.e., intracellular nitrate $=\mathrm{ICNO}_{3}$ ). Subsamples for $\mathrm{ECNO}_{3}$ analysis $(1.5 \mathrm{~mL})$ were cleared from suspended hyphae by mild centrifugation at $1000 \times \mathrm{g}$ for 
$10 \mathrm{~min}$ and the supernatants $\left(\mathrm{S}_{0}\right)$ were stored at $-20^{\circ} \mathrm{C}$ for later analysis. Fungal aggregates for $\mathrm{ICNO}_{3}$ analysis were collected in a 2-mL centrifugation tube and the adhering YMG broth was siphoned off using a hypodermic needle. The aggregates were washed with $1 \mathrm{~mL}$ nitratefree $\mathrm{NaCl}$ solution (2\%) and blotted dry on nitrate-free filter paper. The aggregates were then equally distributed among two $15-\mathrm{mL}$ centrifugation tubes, one for $\mathrm{ICNO}_{3}$ analysis and one for protein analysis.

Aggregates intended for $\mathrm{ICNO}_{3}$ analysis were weighed and thoroughly mixed with $2.5 \mathrm{~mL}$ nitrate-free $\mathrm{NaCl}$ solution (2\%) and centrifuged at $1000 \times \mathrm{g}$ for $5 \mathrm{~min}$. Half a milliliter of the supernatant $\left(S_{1}\right)$ was stored at $-20^{\circ} \mathrm{C}$ for later analysis. To make the fungal hyphae burst and release the $\mathrm{ICNO}_{3}$ into the $\mathrm{NaCl}$ solution, the tube was alternately cooled down to $-196^{\circ} \mathrm{C}$ in liquid nitrogen and heated up to $+90^{\circ} \mathrm{C}$ in a water bath for 5 min each. Cell disruption was additionally promoted by a 1-min treatment with an ultrasonic probe (UW70, Bandelin, Germany). The homogenized hyphae were pelleted by centrifugation at $3000 \times \mathrm{g}$ for $10 \mathrm{~min}$ and the supernatant $\left(\mathrm{S}_{2}\right)$ was stored at $-20^{\circ} \mathrm{C}$ for later analysis.

Aggregates intended for protein analysis were suspended in $4 \mathrm{~mL} 0.5 \mathrm{M} \mathrm{NaOH}$, sonicated for $1 \mathrm{~min}$, and incubated at $+90^{\circ} \mathrm{C}$ for $15 \mathrm{~min}$ for hot alkaline extraction of cellular proteins. The hyphae were pelleted by centrifugation at $3000 \times \mathrm{g}$ for $5 \mathrm{~min}$ and the supernatant was stored at $-20^{\circ} \mathrm{C}$ for later protein analysis according to [60]. Protein extraction was repeated with the pelleted hyphae and the results of the analysis of the two supernatants were combined. A conversion factor (wet weight $\rightarrow$ protein content) was derived and used for calculating the biomass-specific $\mathrm{ICNO}_{3}$ contents as the difference between $\mathrm{NO}_{3}^{-}$concentrations in $\mathrm{S}_{1}$ and $\mathrm{S}_{2}$ divided by the protein contents of the hyphae.

\section{Production of biomass and cellular energy}

The production of biomass and cellular energy by An-4 was studied during aerobic and anaerobic cultivation in the presence or absence of $\mathrm{NO}_{3}^{-}$(Experiment 4). For this purpose, the time courses of protein and ATP contents of An-4 mycelia and of $\mathrm{NO}_{3}^{-}$and $\mathrm{NH}_{4}^{+}$concentrations in the liquid media were followed. Twelve replicate liquid cultures were prepared as described for Experiment 1, but in six cultures $\mathrm{NO}_{3}^{-}$addition was omitted. Six cultures ( 3 cultures each with and without $\mathrm{NO}_{3}^{-}$) were incubated aerobically, whereas the other six cultures (3 cultures each with and without $\mathrm{NO}_{3}^{-}$) were incubated anaerobically. Subsamples of the liquid media $(1.5 \mathrm{~mL})$ and An-4 mycelia (4-6 aggregates) were taken after defined time intervals using aseptic techniques. Samples were immediately frozen at $-20^{\circ} \mathrm{C}$ for later analysis of $\mathrm{NO}_{3}^{-}$ and $\mathrm{NH}_{4}^{+}$concentrations and protein and ATP contents. The $\mathrm{NO}_{3}^{-}$-amended cultures received additional $\mathrm{NO}_{3}^{-}$(to a nominal concentration of $50 \mu \mathrm{mol} \mathrm{L} \mathrm{L}^{-1}$ ) after $1,3,7$, and 9 days of incubation to avoid premature nitrate depletion.

\section{Nitrogen analyses}

Nitrate and $\mathrm{NO}_{2}^{-}$were analyzed with the $\mathrm{VCl}_{3}$ and $\mathrm{NaI}$ reduction assay, respectively $[61,62]$. In these methods, $\mathrm{NO}_{3}^{-}$ and/or $\mathrm{NO}_{2}^{-}$are reduced to nitric oxide that is quantified with the chemiluminescence detector of an $\mathrm{NO}_{\mathrm{x}}$ analyzer (CLD 60, Eco Physics, Munich, Germany). Ammonium was analyzed with the salicylate method [63]. Nitrous oxide was analyzed on a gas chromatograph (GC 7890, Agilent Technologies) equipped with a CP-PoraPLOT Q column and a ${ }^{63} \mathrm{Ni}$ electron capture detector. Isotopically labeled ammonium $\left({ }^{15} \mathrm{NH}_{4}^{+}\right)$was analyzed with the hypobromite oxidation assay [64,65] followed by ${ }^{15} \mathrm{~N}-\mathrm{N}_{2}$ analysis on a gas chromatography-isotopic ratio mass spectrometer (GCIRMS; VG Optima, Manchester, UK). Prior to hypobromite addition, care was taken to remove any $\mathrm{N}_{2}$ possibly produced during the anaerobic incubation by flushing with helium for 5 min. Headspace samples for ${ }^{15} \mathrm{~N}-\mathrm{N}_{2} \mathrm{O}$ and ${ }^{15} \mathrm{~N}$ $\mathrm{N}_{2}$ analysis were taken directly from the incubation exetainers and measured on the GC-IRMS.

\section{ATP analysis}

Biomass-specific contents of adenosine triphosphate (ATP) of An-4 were determined using a modified protocol for ATP quantification in aquatic sediments [66]. Briefly, 1-3 pre-weighed An-4 aggregates were sonicated in $5 \mathrm{~mL}$ of ice-cold extractant $\left(48 \mathrm{mmol} \mathrm{L}^{-1}\right.$ EDTA-Na $\mathrm{Na}_{2}$ in $1 \mathrm{~mol} \mathrm{~L}^{-1}$ $\mathrm{H}_{3} \mathrm{PO}_{4}$ ) for $1 \mathrm{~min}$ and then stored on ice for $30 \mathrm{~min}$. The cell suspension was centrifuged at $3000 \times \mathrm{g}$ for $10 \mathrm{~min}$ and $1 \mathrm{~mL}$ of the supernatant was diluted 1:10 with autoclaved deionized water and adjusted to $\mathrm{pH} 7.8$ with $\mathrm{NaOH}$. An ATP assay mix (FLAAM, Sigma-Aldrich) and a luminometer (TD 20e Luminometer, Turner Designs) were used to quantify the extracted ATP with the firefly bioluminescence reaction. The ATP assay mix was diluted 1:25 with a dilution buffer (FLAAB, Sigma-Aldrich). Calibration standards $\left(0-100 \mu \mathrm{mol} \mathrm{L}^{-1}\right)$ were prepared from ATP disodium salt hydrate (A2383, Sigma-Aldrich) dissolved in 1:10-diluted extractant adjusted to $\mathrm{pH}$ 7.8. Biomass-specific ATP contents of An-4 were calculated from the ATP concentrations of the extracts and the protein contents of the An-4. aggregates.

\section{Additional file}

Additional file 1: Figure S1. Time course of inorganic nitrogen species during anaerobic incubation of $A$. terreus isolate An-4. Figure S2. Phylogenetic position of isolate An-4 in A. terreus [39].

\section{Competing interests}

The authors declare that they have no competing interests. 


\section{Authors' contributions}

TS, PS, TB, and DDB conceived and designed the project. SFO, AK, and PS carried out the experiments and analyzed the data. CSM and JH supplied materials and data. PS wrote the paper with help from all authors. The final manuscript was read and approved by all authors.

\section{Acknowledgements}

We wish to thank Ingrid Dohrmann (MPI Bremen) for skillful help with laboratory analyses. Eckhard Thines (IBWF Kaiserslautern) is acknowledged for providing laboratory facilities. This study was financially supported by grants from the German Research Foundation awarded to P.S. (STI 202/6), A.K. (KA 3187/2-1), and to T.S. (STO 414/3-2) and by the Max Planck Society, Germany.

\section{Author details}

${ }^{1}$ Max Planck Institute for Marine Microbiology, Microsensor Group, Bremen, Germany. '2Department of Biology, University of Southern Denmark, NordCEE, Campusvej 55, 5230 Odense M, Denmark. ${ }^{3}$ Department of Ecology, University of Kaiserslautern, Kaiserslautern, Germany. ${ }^{4}$ Jacobs University Bremen, Molecular Life Science Research Center, Bremen, Germany. ${ }^{5}$ CSIR-National Institute of Oceanography, Dona Paula, Goa, India. ${ }^{6}$ CBS-KNAW Fungal Diversity Centre, Utrecht, The Netherlands. Institute of Microbiology, Chinese Academy of Sciences, Beijing, China.

Received: 31 January 2014 Accepted: 10 February 2014 Published: 11 February 2014

\section{References}

1. Thamdrup B, Dalsgaard T: Nitrogen cycling in sediments. In Microbial ecology of the oceans. Edited by Kirchman DL. Hoboken. John Wiley \& Sons; 2008:527-568.

2. Zumft WG: Cell biology and molecular basis of denitrification. Microbiol Mol Biol Rev 1997, 61:533-616.

3. Strous M, Fuerst JA, Kramer EHM, Logemann S, Muyzer G, Van de Pas-Schoonen KT, et al: Missing lithotroph identified as new planctomycete. Nature 1999, 400:446-449.

4. Cabello P, Roldan MD, Moreno-Vivian C: Nitrate reduction and the nitrogen cycle in archaea. Microbiology-Sgm 2004, 150:3527-3546.

5. Risgaard-Petersen N, Langezaal AM, Ingvardsen S, Schmid MC, Jetten MSM, Op den Camp HJM, et al: Evidence for complete denitrification in a benthic foraminifer. Nature 2006, 443:93-96.

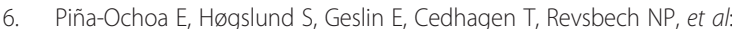
Widespread occurrence of nitrate storage and denitrification among Foraminifera and Gromiida. Proc Natl Acad Sci U S A 2010, 107:1148-1153.

7. Kamp A, de Beer D, Nitsch JL, Lavik G, Stief P: Diatoms respire nitrate to survive dark and anoxic conditions. Proc Natl Acad Sci U S A 2011, 108:5649-5654.

8. Kamp A, Stief P, Knappe J, de Beer D: Response of the ubiquitous pelagic diatom Thalassiosira weissflogii to darkness and anoxia. PLoS One 2013, 8:e82605.

9. Shoun $\mathrm{H}$, Tanimoto T: Denitrification by the fungus Fusarium oxysporum and involvement of cytochrome P-450 in the respiratory nitrite reduction. $\mathrm{J}$ Biol Chem 1991, 266:11078-11082.

10. Takaya N: Response to hypoxia, reduction of electron acceptors, and subsequent survival by filamentous fungi. Biosci Biotechnol Biochem 2009, 73:1-8.

11. Zhou ZM, Takaya N, Nakamura A, Yamaguchi M, Takeo $K$, Shoun $H$ : Ammonia fermentation, a novel anoxic metabolism of nitrate by fungi. J Biol Chem 2002, 277:1892-1896.

12. Jebaraj CS, Raghukumar C, Behnke A, Stoeck T: Fungal diversity in oxygendepleted regions of the Arabian Sea revealed by targeted environmental sequencing combined with cultivation. FEMS Microbiol Ecol 2010 71:399-412.

13. Stoeck T, Behnke A, Christen R, Amaral-Zettler L, Rodriguez-Mora MJ, Chistoserdov $A$, et al: Massively parallel tag sequencing reveals the complexity of anaerobic marine protistan communities. BMC Biol 2009, 7:1-20. Article 72.

14. Epstein S, Lopez-Garcia P: "Missing" protists: a molecular prospective. Biodiv Conserv 2008, 17:261-276.

15. Burgaud G, Woehlke S, Rédou V, Orsi W, Beaudoin D, Barbier G, et al: Deciphering the presence and activity of fungal communities in marine sediments using a model estuarine system. Aquat Microb Ecol 2013, 70:45-62.

16. Mouton M, Postma F, Wilsenach J, Botha A: Diversity and characterization of culturable fungi from marine sediment collected from St. Helena Bay, South Africa. Microb Ecol 2012, 64:311-319.

17. Naqvi SWA, Naik H, Pratihary A, D'Souza W, Narvekar PV, Jayakumar DA, et al: Coastal versus open-ocean denitrification in the Arabian Sea. Biogeosciences 2006, 3:621-633.

18. Ward BB, Devol AH, Rich JJ, Chang BX, Bulow SE, Naik H, et al: Denitrification as the dominant nitrogen loss process in the Arabian Sea. Nature 2009, 461:78-82.

19. Jensen MM, Lam P, Revsbech NP, Nagel B, Gaye B, Jetten MSM, et al: Intensive nitrogen loss over the Omani Shelf due to anammox coupled with dissimilatory nitrite reduction to ammonium. ISME J 2011, 5:1660-1670.

20. Naqvi SWA, Jayakumar DA, Narvekar PV, Naik H, Sarma WSS, D'Souza W, et al: Increased marine production of $\mathrm{N}_{2} \mathrm{O}$ due to intensifying anoxia on the Indian continental shelf. Nature 2000, 408:346-349.

21. Bange HW, Andreae MO, Lal S, Law CS, Naqvi SWA, Patra PK, et al: Nitrous oxide emissions from the Arabian Sea: a synthesis. Atmos Chem Phys 2001, 1:61-71.

22. Takasaki K, Shoun H, Yamaguchi M, Takeo K, Nakamura A, Hoshino T, et al: Fungal ammonia fermentation, a novel metabolic mechanism that couples the dissimilatory and assimilatory pathways of both nitrate and ethanol - Role of acetyl CoA synthetase in anaerobic ATP synthesis. J Biol Chem 2004, 279:12414-12420

23. Kraft B, Strous M, Tegetmeyer HE: Microbial nitrate respiration - Genes, enzymes and environmental distribution. J Biotechnol 2011, 155:104-117.

24. Zhou Z, Takaya N, Shoun H: Multi-energy metabolic mechanisms of the fungus Fusarium oxysporum in low oxygen environments. Biosci Biotechnol Biochem 2010, 74:2431-2437.

25. Usuda K, Toritsuka N, Matsuo Y, Kim DH, Shoun H: Denitrification by the fungus Cylindrocarpon tonkinense - Anaerobic cell-growth and 2 isozyme forms of cytochrome P-450Nor. Appl Environ Microbiol 1995, 61:883-889.

26. Zhou ZM, Takaya N, Sakairi MAC, Shoun H: Oxygen requirement for denitrification by the fungus Fusarium oxysporum. Arch Microbiol 2001 175:19-25.

27. Costa C, Macedo A, Moura I, Moura JJG, Le Gall J, Berlier Y, et al: Regulation of the hexaheme nitrite/nitric oxide reductase of Desulfovibrio desulfuricans, Wolinella succinogenes and Escherichia coli. FEBS Letts 1990, 276:67-70.

28. Kaspar HF, Tiedje JM: Dissimilatory reduction of nitrate and nitrite in the bovine rumen: Nitrous oxide production and effect of acetylene. Appl Environ Microbiol 1981, 41:705-709.

29. Smith MS: Nitrous oxide production by Escherichia coli is correlated with nitrate reductase activity. Appl Environ Microbiol 1983, 45:1545-1547.

30. Fossing H, Gallardo VA, Jørgensen BB, Huettel M, Nielsen LP, Schulz H, et al: Concentration and transport of nitrate by the mat-forming sulfur bacterium Thioploca. Nature 1995, 374:713-715.

31. McHatton SC, Barry JP, Jannasch HW, Nelson DC: High nitrate concentrations in vacuolate, autotrophic marine Beggiatoa spp. Appl Environ Microbiol 1996, 62:954-958.

32. Høgslund S, Revsbech NP, Cedhagen T, Nielsen LP, Gallardo VA: Denitrification, nitrate turnover, and aerobic respiration by benthic foraminiferans in the oxygen minimum zone off Chile. J Exp Mar Biol Ecol 2008, 359:85-91.

33. Bernhard JM, Casciotti KL, Mcllvin MR, Beaudoin DJ, Visscher PT, Edgcomb VP: Potential importance of physiologically diverse benthic foraminifera in sedimentary nitrate storage and respiration. J Geophys Res-Biogeosci 2012, 117:1-14. Article G03002.

34. Lomas MW, Glibert PM: Comparisons of nitrate uptake, storage, and reduction in marine diatoms and flagellates. J Phycol 2000, 36:903-913.

35. Needoba JA, Harrison PJ: Influence of low light and a light: dark cycle on $\mathrm{NO}_{3}^{-}$uptake, intracellular $\mathrm{NO}_{3}^{-}$, and nitrogen isotope fractionation by marine phytoplankton. J Phycol 2004, 40:505-516.

36. Koho KA, Pina-Ochoa E, Geslin E, Risgaard-Petersen N: Vertical migration, nitrate uptake and denitrification: survival mechanisms of foraminifers (Globobulimina turgida) under low oxygen conditions. FEMS Microbiol Ecol 2011, 75:273-283.

37. Stief $P$, Kamp A, de Beer D: Role of diatoms in the spatial-temporal distribution of intracellular nitrate in intertidal sediment. PLoS One 2013, 8:e73257. 
38. Beutler M, Milucka J, Hinck S, Schreiber F, Brock J, Mussmann M, et al: Vacuolar respiration of nitrate coupled to energy conservation in filamentous Beggiatoaceae. Environ Microbiol 2012, 14:2911-2919.

39. Samson RA, Peterson SW, Frisvad JC, Varga J: New species in Aspergillus section Terrei. Stud Mycol 2011, 69:39-55.

40. Barakat KM, Gohar YM: Antimicrobial agents produced by marine Aspergillus terreus var. africanus against some virulent fish pathogens. Indian J Microbiol 2012, 52:366-372.

41. He F, Bao J, Zhang XY, Tu ZC, Shi YM, Qi SH: Asperterrestide A, a cytotoxic cyclic tetrapeptide from the marine-derived fungus Aspergillus terreus SCSGAF0162. J Nat Prod 2013, 76:1182-1186.

42. Parvatkar RR, D'Souza C, Tripathi A, Naik CG: Aspernolides A and B, butenolides from a marine-derived fungus Aspergillus terreus. Phytochem 2009, 70:128-132.

43. Grishkan I, Nevo E, Wasser SP: Soil micromycete diversity in the hypersaline Dead Sea coastal area, Israel. Mycol Prog 2001, 2:19-28.

44. Oren A, Gunde-Cimerman N: Fungal life in the Dead Sea. Prog Mol Subcell Biol 2012, 53:115-132.

45. Iwen PC, Rupp ME, Langnas AN, Reed EC, Hinrichs SH: Invasive aspergillosis due to Aspergillus terreus: 12-year experience and review of the literature. Clin Infect Diseases 1998, 26:1092-1097.

46. Lundberg JO, Weitzberg E, Cole JA, Benjamin N: Opinion - Nitrate, bacteria and human health. Nature Rev Microbio/ 2004, 2:593-602.

47. Schreiber F, Stief P, Gieseke A, Heisterkamp IM, Verstraete W, de Beer D, et al: Denitrification in human dental plaque. BMC Biol 2010, 8:1-11. Article 24.

48. Revsbech NP, Jørgensen BB, Blackburn TH: Oxygen in the sea bottom measured with a microelectrode. Science 1980, 207:1355-1356.

49. Stief $P$, Nazarova L, de Beer D: Chimney construction by Chironomus riparius larvae in response to hypoxia: microbial implications for freshwater sediments. J N Am Benthol Soc 2005, 24:858-871.

50. Heisterkamp IM, Kamp A, Schramm AT, de Beer D, Stief P: Indirect control of the intracellular nitrate pool of intertidal sediment by the polychaete Hediste diversicolor. Mar Ecol Prog Ser 2012, 445:181-192.

51. Precht E, Franke U, Polerecky L, Huettel M: Oxygen dynamics in permeable sediments with wave-driven pore water exchange. Limnol Oceanogr 2004, 49:693-705.

52. Stief $P$, de Beer D: Probing the microenvironment of freshwater sediment macrofauna: Implications of deposit-feeding and bioirrigation for nitrogen cycling. Limnol Oceanogr 2006, 51:2538-2548.

53. Wright JJ, Konwar KM, Hallam SJ: Microbial ecology of expanding oxygen minimum zones. Nature Rev Microbiol 2012, 10:381-394.

54. Dickinson RE, Cicerone RJ: Future global warming from atmospheric trace gases. Nature 1986, 319:109-115.

55. Ravishankara AR, Daniel JS, Portmann RW: Nitrous oxide $\left(\mathrm{N}_{2} \mathrm{O}\right)$ : the dominant ozone-depleting substance emitted in the 21 st century. Science 2009, 326:123-125.

56. Naqvi SWA, Bange HW, Farias L, Monteiro PMS, Scranton Ml, Zhang J: Marine hypoxia/anoxia as a source of $\mathrm{CH}_{4}$ and $\mathrm{N}_{2} \mathrm{O}$. Biogeosciences 2010, 7:2159-2190.

57. Houbraken J, Frisvad JC, Samson RA: Taxonomy of Penicillium section Citrina. Stud Mycol 2011, 70:53-138.

58. Houbraken J, Spierenburg H, Frisvad JC: Rasamsonia, a new genus comprising thermotolerant and thermophilic Talaromyces and Geosmithia species. Antonie Van Leeuwenhoek 2012, 101:403-421.

59. Muyzer G, Teske A, Wirsen CO, Jannasch HW: Phylogenetic relationships of Thiomicrospira species and their identification in deep-sea hydrothermal vent samples by Denaturing Gradient Gel Electrophoresis of 16S rDNA fragments. Arch Microbiol 1995, 164:165-172.

60. Lowry OH, Rosebrough NJ, Farr AL, Randall RJ: Protein measurement with the folin phenol reagent. J Biol Chem 1951, 193:265-275.

61. Braman RS, Hendrix SA: Nanogram nitrite and nitrate determination in environmental and biological materials by vanadium(III) reduction with chemiluminescence detection. Anal Chem 1989, 61:2715-2718.

62. Yang F, Troncy E, Francoeur M, Vinet B, Vinay P, Czaika G, Blaise G: Effects of reducing reagents and temperature on conversion of nitrite and nitrate to nitric oxide and detection of NO by chemiluminescence. Clin Chem 1997, 43:657-662.

63. Bower CE, Holm-Hansen T: A salicylate-hypochlorite method for determining ammonia in seawater. Can J Fish Aquat Sci 1980, 37:794-798.
64. Warembourg FR: Nitrogen fixation in soil and plant systems. In Nitrogen isotope techniques. Edited by Knowles R, Blackburn TH. New York: Academic; 1993:157-180.

65. Risgaard-Petersen N, Rysgaard S, Revsbech NP: Combined microdiffusionhypobromite oxidation method for determining ${ }^{15} \mathrm{~N}$ isotope in ammonium. Soil Sci Soc Am J 1995, 59:1077-1080.

66. Stief $\mathrm{P}$, de Beer $\mathrm{D}$ : Bioturbation effects of Chironomus riparius on the benthic $\mathrm{N}$-cycle as measured using microsensors and microbiological assays. Aquat Microb Ecol 2002, 27:175-185.

doi:10.1186/1471-2180-14-35

Cite this article as: Stief et al:: Dissimilatory nitrate reduction by Aspergillus terreus isolated from the seasonal oxygen minimum zone in the Arabian Sea. BMC Microbiology 2014 14:35.

\section{Submit your next manuscript to BioMed Central and take full advantage of:}

- Convenient online submission

- Thorough peer review

- No space constraints or color figure charges

- Immediate publication on acceptance

- Inclusion in PubMed, CAS, Scopus and Google Scholar

- Research which is freely available for redistribution 